\title{
Effect of iron dextran injection on growth performance of crossbred and desi piglets under farm and village conditions
}

\author{
Raghuvir Ranjan, Chandra Mani Prasad, Sanjit Kumar Singh \\ Ranchi Veterinary College, Birsa Agricultural University, Ranchi - 6, Jharkhand, India. \\ Corresponding author: Sanjit Kumar Singh, email: drsanjit_2850@yahoo.co.in \\ Received: 27-03-2012, Accepted: 19-04-2012 \\ doi: $10.5455 /$ vetworld.2012.599-602
}

\begin{abstract}
Aim: To study the effect of iron dextran injection on growth performance of crossbred and desi piglets under farm and village conditions.

Materials and Methods: The experiments were conducted in Pig Breeding Farm, Ranchi Veterinary College, Ranchi and different villages on crossbred and desi preweaned piglets. The piglets were divided into three treatment groups as $T_{1}$ (control), $\mathrm{T}_{2}$ (injected iron dextran @ $1 \mathrm{ml}(50 \mathrm{mg}) \mathrm{I} / \mathrm{M}$ twice at $3^{\text {rd }}$ and $14^{\text {th }}$ days of age) and $\mathrm{T}_{3}$ (injected iron dextran @ $2 \mathrm{ml}$ (100mg) I/M once at $3^{\text {rd }}$ day of age).

Results: The average body weight of crossbred piglets in farm condition of $\mathrm{T}_{1}, \mathrm{~T}_{2}$ and $\mathrm{T}_{3}$ groups at weaning ( 8 week) were $7.162 \pm 0.365,9.985 \pm 0.281$ and $9.572 \pm 0.295 \mathrm{~kg}$, respectively. The piglets of $\mathrm{T}_{2}$ group showed better performance over $\mathrm{T}_{3}$ and $\mathrm{T}_{1}$ groups in farm and village conditions on crossbred and desi piglets.

Conclusion: On the basis of present findings it may be concluded that iron dextran $(50 \mathrm{mg} / \mathrm{ml})$ injection should be given to all piglets @ $1 \mathrm{ml} \mathrm{I/M}$ during preweaning period at $3^{\text {rd }}$ and $14^{\text {th }}$ day of age for better growth of piglets.

Keywords: Desi and crossbred Piglets, Growth, Iron dextran injection, Farm and Village conditions.
\end{abstract}

To cite this article: Ranjan R, Prasad CM, Singh SK (2012) Effect of iron dextran injection on growth performance of crossbred and desi piglets under farm and village conditions, Vet World, 5(10): 599-602, doi: 10.5455/ vetworld.2012.599-602

\section{I ntroduction}

Pig is associated with human civilization since long back as Barah Awatar mentioned in holy book "Vishnu Puran". Even today in some part of the country, especially tribal dominated state/ region, it is known as festive food. As such, pig farming is an age old practice in our country. In plateu region of Jharkhand, it is very popular among tribal \& socioeconomically backward people in rural and semiurban areas. Pig farming is very lucrative and easy source of regular income as fast growing, important source of animal protein, short generation interval and better feed conversion efficiency with higher dressing percentage. Piglets are traditionally weaned at about 56 days of age, when they can utilize as feed themselves of both animal and plant origin and have developed immunity to resist infection. However, 15 to $20 \%$ of total piglets born do not survive till weaning age. The highest pig mortality upto $80 \%$ of total death occurs during pre-weaning period (0-8 weeks) specially, during first week of life. The preweaning mortality was up to $21 \%$ in 2-3 weeks of age [1]. The piglet anaemia, caused by iron deficiency, is one of the major reasons of preweaning mortality. When a piglet is born, it has sufficient iron to last for 3-7 days, after that sufficient iron must be supplied either through parenteral or oral sources. Under natural conditions, baby pigs may obtain sufficient iron from soil, but most pigs today are farrowed and reared indoors and thus have no access to soil. Unless iron is obtained from another source, the pigs may die. Workers [2] observed higher body weight gain with iron dextran injection in suckling piglets. Keeping in view the above ideas, the present study has been planned to see the effect of different doses of iron dextran $(50 \mathrm{mg} / \mathrm{ml})$ injection in preweaning piglets in farm and village conditions.

\section{Materials and Methods}

The experiments were conducted in farm viz. Pig Breeding Farm, Ranchi Veterinary College, Ranchi and different villages viz. Kuchu, Borea and Garu. In 
Effect of iron dextran injection on growth performance of crossbred and desi piglets under farm and village conditions

Table-1. Average body weight $(\mathrm{kg})$ at various ages in different treatment groups under farm condition in crossbred piglets

\begin{tabular}{lccc}
\hline Age (week) & $\mathbf{T}_{1}$ & Different treatment groups & $\mathbf{T}_{\mathbf{3}}$ \\
\hline At birth & $0.998 \pm 0.032(56)$ & $0.977 \pm 0.035(57)$ & $0.964 \pm 0.032(58)$ \\
$1^{\text {st }}$ & $2.048 \pm 0.057(56)$ & $2.096 \pm 0.064(55)$ & $2.002 \pm 0.061(57)$ \\
$2^{\text {nd }}$ & $2.892 \pm 0.088(56)$ & $3.137 \pm 0.095(54)$ & $2.953 \pm 0.098(56)$ \\
$3^{\text {td }}$ & $3.655 \pm 0.121(56)$ & $4.152 \pm 0.111(54)$ & $3.943 \pm 0.122(56)$ \\
$4^{\text {th }}$ & $4.349 \pm 0.149^{\mathrm{a}}(54)$ & $5.204 \pm 0.130^{\mathrm{b}}(54)$ & $4.923 \pm 0.1600^{\mathrm{b}}(56)$ \\
$5^{\text {th }}$ & $4.898 \pm 0.196^{\mathrm{a}}(54)$ & $6.205 \pm 1.076^{\mathrm{b}}(54)$ & $5.927 \pm 0.188^{\mathrm{b}}(55)$ \\
$6^{\text {th }}$ & $5.566 \pm 0.244^{\mathrm{a}}(54)$ & $7.428 \pm 0.197^{\mathrm{b}}(53)$ & $7.049 \pm 0.223^{\mathrm{b}}(55)$ \\
$7^{\text {th }}$ & $6.357 \pm 0.314^{\mathrm{a}}(54)$ & $8.730 \pm 0.247^{\mathrm{b}}(53)$ & $8.364 \pm 0.248^{\mathrm{b}}(55)$ \\
$8^{\text {th }}$ & $7.162 \pm 0.365^{\mathrm{a}}(52)$ & $9.985 \pm 0.281^{\mathrm{b}}(53)$ & $9.572 \pm 0.295^{\mathrm{b}}(55)$ \\
\hline
\end{tabular}

Mean under same superscripts in a row did not differ significantly. Figures in parentheses indicate number of observations.

farm condition, a total of 232 pre-weaned piglets from 32 different sows (171 preweaned crossbred piglets from 21 sows and 61 desi piglets from 11 sows) were taken and divided into three treatment groups as $\mathrm{T}_{1}, \mathrm{~T}_{2}$ and $\mathrm{T}_{3}$. All piglets of different experimental groups were fed the standard farm diet consisting of crushed maize (67\%), G.N. cake (20\%), wheat bran (5\%), fish meal $(7 \%)$, salt $(0.5 \%)$ and Min. Mixture $(0.5 \%)+$ Rovi mix (20g). In village condition, a total of 82 preweaned crossbred piglets from 10 different sows were taken and divided into three treatment groups as $\mathrm{T}_{1}, \mathrm{~T}_{2}$ and $\mathrm{T}_{3}$. All piglets of different experimental groups were fed the feed available with the farmers in the village condition. Piglets of first group $\left(T_{1}\right)$ were kept as control, second group $\left(\mathrm{T}_{2}\right)$ were injected iron dextran @ $1 \mathrm{ml}(50 \mathrm{mg} / \mathrm{ml}) \mathrm{I} / \mathrm{M}$ twice at $3^{\text {rd }}$ and $14^{\text {th }}$ days of age and third group $\left(\mathrm{T}_{3}\right)$ were injected iron dextran @ $2 \mathrm{ml} \mathrm{I} / \mathrm{M}$ once at $3^{\text {rd }}$ day of age in both conditions viz. farm and village. The guidelines and rules of Animal Ethics Committee were followed during the experimental period. The body weight of all piglets was taken at birth and at weekly interval upto $8^{\text {th }}$ weeks of age with the help of spring balance. Statistical analysis of data collected during the experiment were analysed [3].

\section{Results and Discussion}

The average body weight of crossbred piglets in farm condition for different treatment groups during preweaning period are presented in Table- 1 . The difference in body weights of the piglets in $\mathrm{T}_{2}$ and $\mathrm{T}_{3}$ groups were non-significant. The average body weights of $\mathrm{T}_{1}, \mathrm{~T}_{2}$ and $\mathrm{T}_{3}$ groups at weaning $\left(8^{\text {th }}\right.$ week $)$ were $7.162 \pm 0.365,9.985 \pm 0.281$ and $9.572 \pm 0.295 \mathrm{~kg}$, respectively. The body weight of the rabbit of $\mathrm{T}_{2}$ and $\mathrm{T}_{3}$ group were significantly $(\mathrm{P}<0.05)$ higher than $\mathrm{T}_{1}$. But
$\mathrm{T}_{2} \& \mathrm{~T}_{3}$ were non-significant among themselves. The average body weight of crossbred piglets for $\mathrm{T}_{2}$ group was higher than $\mathrm{T}_{3}$ and $\mathrm{T}_{1}$ groups during $3^{\text {rd }}$ week of age. Almost similar findings were reported by Worker [4] who also reported significantly higher body weight of piglets injected with $200 \mathrm{mg}$ of Iron in piglets weaned at third week of age. The parenteral and oral Iron supplemented groups of piglets showed significantly higher body weight than unsupplemented groups [2,5,6]. Workers [7] also observed that $\mathrm{Fe}$ injected pre-weaning affected initial post-weaning performance. From $4^{\text {th }}$ week onward the body weight was significantly $(\mathrm{p}<0.01)$ lower in $\mathrm{T}_{1}$ control group than $\mathrm{T}_{2}$ and $\mathrm{T}_{3}$ groups (Table-1). The poor growth rate in $\mathrm{T}_{1}$ group might be due to deprived of Iron through parenterally and hence low haemoglobin level; anorexia and diarrhoea also be attributed cause. Workers [8] also reported significant increase in the body weights of all treated piglets in comparison to their respective iron-deprived groups. Growth rate was interfered when haemoglobin level drops to about $5 \mathrm{~g} \%$ [9].

The body weight of desi piglets under farm conditions for different treatment groups are presented in Table-2. The parenteral administration $50 \mathrm{mg}$ of Iron at $3^{\text {rd }}$ and $14^{\text {th }}$ days of age $\left(\mathrm{T}_{2}\right)$ and $100 \mathrm{mg}$ of Iron at $3^{\text {rd }}$ days $\left(\mathrm{T}_{3}\right)$ showed, significantly $(\mathrm{p}<0.01)$ higher body weight gain from $4^{\text {th }}$ to $8^{\text {th }}$ week of age over untreated group $\left(\mathrm{T}_{1}\right)$. However, $\mathrm{T}_{2}$ had shown significantly $(p<0.01)$ higher body weight from $1^{\text {st }}$ to $3^{\text {rd }}$ week of age over $T_{1}$ and $T_{3}$. The body weights of piglets on untreated groups were almost similar to the findings of Worker [10] who reported 3.8 to $4.0 \mathrm{~kg}$ body weight at 60 days of age. The responses of Iron dextran injection for desi piglets were similar to crossbred piglets. 
Effect of iron dextran injection on growth performance of crossbred and desi piglets under farm and village conditions

Table-2. Average body weight $(\mathrm{kg})$ at various ages of different treatment groups in desi piglets under farm condition.

\begin{tabular}{lccc}
\hline Age (week) & $\mathbf{T}_{1}$ & Different treatment groups & $\mathbf{T}_{\mathbf{3}}$ \\
\hline At birth & $0.709 \pm 0.039(21)$ & $0.685 \pm 0.406(20)$ & $0.685 \pm 0.043(20)$ \\
$1^{\text {st }}$ & $1.070 \pm 0.053^{\mathrm{a}}(20)$ & $1.331 \pm 0.068^{\mathrm{b}}(19)$ & $1.105 \pm 0.043^{\mathrm{a}}(19)$ \\
$2^{\text {nd }}$ & $1.505 \pm 0.082^{\mathrm{a}}(19)$ & $2.116 \pm 0.111^{\mathrm{b}}(19)$ & $1.631 \pm 0.750^{\mathrm{a}}(19)$ \\
$3^{\text {rd }}$ & $1.900 \pm 0.108^{\mathrm{a}}(19)$ & $2.631 \pm 0.171^{\mathrm{b}}(19)$ & $2.258 \pm 0.126^{\mathrm{a}}(19)$ \\
$4^{\text {th }}$ & $2.131 \pm 0.113^{\mathrm{a}}(19)$ & $3.026 \pm 0.179^{\mathrm{b}}(19)$ & $2.800 \pm 0.146^{\mathrm{b}}(19)$ \\
$5^{\text {th }}$ & $2.333 \pm 0.098^{\mathrm{a}}(18)$ & $3.395 \pm 0.225^{\mathrm{b}}(19)$ & $3.205 \pm 0.172^{\mathrm{b}}(19)$ \\
$6^{\text {th }}$ & $2.523 \pm 0.167^{\mathrm{a}}(13)$ & $3.826 \pm 0.243^{\mathrm{b}}(19)$ & $3.774 \pm 0.185^{\mathrm{b}}(19)$ \\
$7^{\text {th }}$ & $3.015 \pm 0.240^{\mathrm{a}}(13)$ & $4.389 \pm 0.259^{\mathrm{b}}(19)$ & $4.353 \pm 0.200^{\mathrm{b}}(19)$ \\
$8^{\text {th }}$ & $3.454 \pm 0.282^{\mathrm{a}}(13)$ & $5.021 \pm 0.311^{\mathrm{b}}(19)$ & $4.921 \pm 0.249^{\mathrm{b}}(19)$ \\
\hline
\end{tabular}

Mean under same superscripts in a row did not differ significantly. Figures in parentheses indicate number of observations.

Table-3. Average body weight $(\mathrm{kg})$ at various ages in different treatment groups under village condition in crossbred piglets.

\begin{tabular}{lccc}
\hline Age (week) & $\mathbf{T}_{1}$ & Different treatment groups & $\mathbf{T}_{3}$ \\
\hline At birth & $0.919 \pm 0.037(26)$ & $0.878 \pm 0.045(28)$ & $0.936 \pm 0.043(28)$ \\
$1^{\text {st }}$ & $1.813 \pm 0.078(23)$ & $1.836 \pm 0.099(25)$ & $1.768 \pm 0.096(25)$ \\
$2^{\text {nd }}$ & $2.574 \pm 0.111(23)$ & $2.800 \pm 0.173(24)$ & $2.596 \pm 0.132(24)$ \\
$3^{\text {td }}$ & $3.252 \pm 0.178(23)$ & $3.822 \pm 0.191(23)$ & $3.437 \pm 0.165(24)$ \\
$4^{\text {th }}$ & $3.967 \pm 0.223^{\mathrm{a}}(21)$ & $4.856 \pm 0.221^{\mathrm{b}}(23)$ & $4.336 \pm 0.217^{\mathrm{ab}}(22)$ \\
$5^{\text {th }}$ & $4.490 \pm 0.268^{\mathrm{a}}(20)$ & $5.873 \pm 0.289^{\mathrm{b}}(22)$ & $5.009 \pm 0.262^{\mathrm{ab}}(22)$ \\
$6^{\text {th }}$ & $4.910 \pm 0.269^{\mathrm{a}}(20)$ & $6.709 \pm 0.281^{\mathrm{b}}(22)$ & $5.848 \pm 0.287^{\mathrm{c}}(21)$ \\
$7^{\text {th }}$ & $5.450 \pm 0.336^{\mathrm{a}}(20)$ & $7.732 \pm 0.352^{\mathrm{b}}(22)$ & $6.800 \pm 0.328^{\mathrm{c}}(21)$ \\
$8^{\text {th }}$ & $5.900 \pm 0.394^{\mathrm{a}}(20)$ & $8.509 \pm 0.373^{\mathrm{b}}(22)$ & $7.709 \pm 0.354^{\mathrm{b}}(21)$ \\
\hline
\end{tabular}

Mean under same superscripts in a row did not differ significantly. Figures in parentheses indicate number of observations.

The average body weight of crossbred piglets for different treatment groups under village conditions are presented in Table-3. The parenteral injection of $50 \mathrm{mg}$ of Iron on $3^{\text {rd }}$ and $14^{\text {th }}$ day $\left(\mathrm{T}_{2}\right)$ and $100 \mathrm{mg}$ of Iron parenterally $\left(\mathrm{T}_{3}\right)$ on $3^{\text {rd }}$ day in crossbred piglets indicated non-significant effect with that of untreated group $\left(T_{1}\right)$. The effect on body weight for $T_{2}$ and $T_{3}$ were also non-significant from birth to $3^{\text {rd }}$ week of age. The piglets with $T_{2}$ group showed significantly $(\mathrm{p}<0.01)$ higher body weight than control during $4^{\text {th }}$ to $8^{\text {th }}$ week of age. However, $T_{2}$ group of piglet showed significantly $(\mathrm{p}<0.01)$ higher body weight than $\mathrm{T}_{3}$ during $6^{\text {th }}$ and $7^{\text {th }}$ week. It is very clear from the findings that $50 \mathrm{mg}$ of Iron injection on $3^{\text {rd }}$ and $14^{\text {th }}$ day $\left(\mathrm{T}_{2}\right)$ certainly showed better performance over $100 \mathrm{mg}$ Iron injection on $3^{\text {rd }}$ day $\left(\mathrm{T}_{3}\right)$ and untreated control $\left(\mathrm{T}_{1}\right)$ groups. No information is available for the performance of Iron dextran injection on crossbred piglets in village condition. The performance of crossbred piglets on different treatments under farm condition was better than village condition.

Supplementation of 50 to $150 \mathrm{ppm} \mathrm{Fe}$ in the grower and finisher diet increased the daily gain of growing pig [11]. The piglets injected with iron dextran injection had better growth performance than supplemented with iron in paste form and drinking water [12]. Combination of L-Carnitine + Fe supplementations increased the growth performance of growing pig whereas supplementation of L-Carnitine without $\mathrm{Fe}$ does not have any effect on growth performance [13]. Above findings are almost similar with the findings of present study. Workers [14] also reported that supplementation of iron and copper during last week of gestation was beneficial for maintaining normal haemoglobin levels and total erythrocyte counts in new born piglets which may be beneficial in the growth performance of the piglets.

\section{Conclusion}

On the basis of present findings, it may be concluded that iron dextran injection should be given to all piglets @ $1 \mathrm{ml} \mathrm{I} / \mathrm{M}$ during preweaning period at $3^{\text {rd }}$ and $14^{\text {th }}$ day of age for better growth.

\section{Author's contribution}

Raghuvir Ranjan carried out the experiment. Chandra 
Mani Prasad designed the experiment, guided during the experiment and helped in drafting of manuscript. Sanjit Kumar Singh analysed data, sample and wrote the final draft of manuscript. All authors read and approved the final manuscript.

\section{Acknowledgements}

The authors are thankful to The Directorate of Research, Birsa Agricultural University, Ranchi for providing the facilities.

\section{Competing interest}

Authors declares that they have no competing interest.

\section{References}

1. Dutta, B. and Rahman, T. (2006). Epidemiological studies on the preweaning mortality of piglets in organized farm of Assam. Indian Vet. J., 83: 376.

2. Pechin, G. H., Fournier, M. T., Sanchez, F. O. and Cesan, R. O. (1998). Effect of iron dextran administration on weight gain and blood parameters related to iron metabolism in suckling piglets raised in contact with soil. Revista de medicina veterinaria Buenos Aires. 79: 118.

3. Snedecor, G. W. and Cochran, W. G. (1994) Statistical Methods, $9^{\text {th }}$ edn., lowa State Univ. Press, Ames, U. S. A.

4. Daykin, M.M.; Griffiths, A.J. and Towlerton,R.G. (1982). Evaluation of the parenteral iron requirement of early weaned pigs. Veterinary Record.; $110: 535$.

5. Kay, R.M.; Gleed, P.T.; Patterson, A. and Sansom, B.F. (1980). Effect of low level dosing of iron on the haematological and growth of piglets. Veterinary Record.; 408-410.

6. Sarma, K; Rehman, A.; Baruah, K.K. and Neog, B.N. (2000). Effect of oral and parenteral administration of iron on growth rates, blood iron and copper levels in unweaned piglets. Indian Vet. J. 77 (11): 1000.

7. Jolliff, J.S. and Mahan, D.C. (2011-12). Effect of injected and dietary iron in young pigs on blood haematology and postnatal pig growth performance. J.Anim. Sci., 89(12): 4068.

8. Rajkhowa, S.; Hazarika, G. C. and Sarma, S. (2008). Effed of different iron preparations on body weight gain of anaemic piglets and iron deficient anaemic calves. Indian J. Anim. Sci. 78(1): 111.

9. Matrone, Gennard, E.L.; Thomason, E.J., Jr. and Bunn, C.R. (1960). Requirement and utilization of iron by the baby pig, J. Nutr. 72: 459 .

10. Seaeendran, P.C. and Rajagopalan, T.G. (1982). Note on the potentialities of indogenous and exotic pigs. Indian J. Anim. Sci., 52 (3): 199.

11. Apple, J. K., Wallis-Phelps, W. A., Maxwell, C. V., Rakes, L. K., Sawyer, J. T., Hutchison, S. and Faklar, T. M. (2007). Effects of supplementatal iron on finishing swine performance, carcass characteristics and pork quality during retail display. Journal of Animal Science. 85: 737.

12. Loh Teck Chwen, Leong Kah Heng, Too Heng Lee, Mah Choew Kong and Choo Pow Yoon. (2001). The Effects of Iron Supplementation in Preweaning Piglets. Mal J. Nutr.7(1\&2): 41.

13. Arkadiusz Pietruszka, Eugenia Jacyno, Anita Kolodziej, Maria Kawecka, Czeslaw Elzanowski and Beata Matysiak. (2009). Effect of L-Carnitine and iron supplementations on growth performance, carcass characteristics and blood metabolites in fattening pigs. Agricultural and Food Science. 18: 27.

14. Sirohi, A.S.; Singla, M,; Nagra, S.S. and Jindal, R. (2011). Influence of iron and copper supplementation to advanced pregnant sows on the haematological parameters of their piglets. Indian J. Anim. Sci. 81(8): 834. 